\title{
EFFEKTIVITAS SUPLEMENTASI VITAMIN D DALAM MEMPERCEPAT KONVERSI SPUTUM PADA PASIEN TUBERKULOSIS
}

\section{THE EFFECTIVENESS OF VITAMIN D SUPPLEMENTATION IN ACCELERATING TIME TO SPUTUM CONVERSION}

\author{
Muhammad Sobri Maulana ${ }^{1}$, Nurfadhilah Al Adabiyah ${ }^{2}$ \\ ${ }^{1}$ Profesi Pendidikan Dokter Fakultas Kedokteran Universitas Indonesia, Jakarta \\ ${ }^{2}$ Universitas Mataram
}

*) muhammadsobrimaulana31@gmail.com

\begin{abstract}
ABSTRAK
Latar Belakang: Tuberculosis merupakan penyakit infeksi oleh Mycobacterium tuberculosis. Tuberculosis merupakan salah satu diantara sepuluh penyebab utama kematian di dunia. Penelitian terdahulu membuktikan bahwa suplementasi vitamin D dapat meningkatkan aktivitas anti-mikrobial, mempercepat konversi sputum dan kultur, mengurangi inflamasi, meningkatkan clinical outcome, serta meningkatkan mediator untuk aktivitas anti-mikrobial. Meskipun demikian, masih terdapat perbedaan pendapat akan manfaat suplementasi vitamin $D$ pada pasien tuberculosis paru.Tujuan: Mengevaluasi bukti yang ada sampai saat ini terkait manfaat suplementasi vitamin $D$ terutama dalam mempercepat konversi sputum. Metode: Pencarian literatur dilakukan pada tiga databases terkemuka yakni PubMed, SCOPUS, dan Cochrane dengan kata kunci berupa "Tuberculosis", "Vitamin D", "Suplementation", dan "Sputum Conversion" dengan seluruh kata yang berhubungan. Dari seleksi artikel berdasarkan kriteria inklusi dan eksklusif didapatkan 1 systematic review oleh Jollifee D et al (2019) dan 1 clinical trial oleh Afzal A et al (2018), yang kemudian ditelaah berdasarkan aspek validity, importance, dan applicability menggunakan form telaah dari Oxford Center for Evidence Based Medicine. Hasil: Kedua artikel memenuhi kriteria validity, importance, dan applicability masing-masing. Dari segi efikasi, penelitian Jollifee $D$ et al membuktikan bahwa pemberian suplementasi vitamin $D$ tidak mempercepat konversi kultur sputum pada populasi umum (aHR 1.06, 95\% $\mathrm{Cl} 0.91-1.23 ; \mathrm{P}=0.44 ; \mathrm{P}$ for heterogeneity=0.84), namun mempercepat konversi kultur sputum pada populasi MDR-TB(aHR 13.44, 95\% Cl 2.96-60.90). Kedua studi membuktikan bahwa pemberian suplementasi vitamin D mampu mempercepat konversi apusan sputum namun konversi apusan sputum memiliki validitas yang lebih rendah sebagai marker prognosis untuk outcome suatu tatalaksana dibandingkan konversi kultur sputum. Kesimpulan: Pemberian suplementasi vitamin D tidak mempercepat konversi kultur sputum namun mempercepat konversi apusan sputum. Diperlukan penelitian lebih lanjut terkait manfaat suplementasi vitamin D pada percepatan konversi kultur sputum populasi MDR-TB.
\end{abstract}

Kata Kunci: Tuberkulosis, Vitamin D, Suplementasi, Konversi Sputum

\section{ABSTRACT}

Background: Tuberculosis in an infectious disease caused by Mycobacterium tuberculosis bacteria. Tuberculosis is one of the top ten leading cause of death in the world. Previous studies showed that vitamin D supplementation could enhance anti-microbial activity, time to sputum and culture conversion, reduce inflammation, improve clinical outcome, and act as a mediator for anti-microbial activity. However, there is still a controversy whether the vitamin D supplementation will give benefit in pulmonary tuberculosis. Objective: To evaluate current evidence in the benefit of vitamin D supplementation especially in reducing the time to sputum conversion. Methods: Literature searching process was conducted on three databases PubMed, SCOPUS, dan Cochrane with the keywords "Tuberculosis", "Vitamin D", "Suplementation", and "Sputum Conversion" along with their synonyms. After applying the inclusion and exclusion criteria, we found 1 systematic review by Jollifee D et al (2019) and 1 clinical trial by Afzal A et al (2018). The articles then critically appraised in the aspect of validity, importance, and applicability by using the critical appraisal tools from Oxford Center for Evidence Based Medicine. Result: Both articles fulfilled their own validity, importance, and applicability criteria. In efficacy aspect, Jollifee $D$ et al proved that vitamin $D$ supplementation did not accelerate the tome to sputum culture conversion in general population (aHR 1.06, 95\% $\mathrm{Cl} 0.91-1.23 ; \mathrm{P}=0.44 ; \mathrm{P}$ for heterogeneity=0.84), however it did accelerate time to sputum culture conversion in MDR-TB population (aHR 13.44, 95\% Cl 2.96-60.90). Both studies proved that vitamin D supplementation indeed reducing the time to sputum smear conversion, however this parameter has lower validity as a prognostic marker for tuberculosis treatment outcome.Conclusion: Vitamin D supplementation did not accelerate the tome to sputum culture conversion. Further studies are needed to find the effect of vitamin $D$ supplementation in reducing time to sputum culture conversion in MDR-TB population.

Keywords: Tuberculosis, Vitamin D, Supplementation, Sputum Conversion

\section{PENDAHULUAN}

Tuberculosis (TB) merupakan

infeksi kuman mycobacterium tuberculosis

pada tubuh terutama pada paru.

Tuberculosis merupakan salah satu permasalahan utama kesehatan global. Pada tahun 2018, TB menjadi salah satu diantara sepuluh penyebab kematian utama di dunia. Diperkirakan terdapat sekitar 10 juta kasus baru TB secara global 
dengan angka kematian berkisar 1.5 juta. Indonesia sendiri, berada pada peringkat ke-3 negara dengan jumlah penderita TB terbanyak. Pada tahun 2019, jumlah penderita TB di Indonesia diperkirakan sebanyak 845 ribu jiwa dengan angka mortalitas 98 ribu jiwa. Diantara penderita TB di Indonesia, $60 \%$ diantaranya adalah pria, $32 \%$ wanita, sementara $8 \%$ sisanya merupakan anak-anak.

Tuberculosis bersifat merugikan karena tidak hanya membawa beban finansial yang berat bagi suatu negara, namun juga mengurangi angka kualitas hidup bagi penderitanya baik dalam aspek fungsional fisik maupun psikologis. Pengobatan yang memakan waktu lama juga seringkali membuat masalah baru berupa ketidakpatuhan pasien dalam pengobatan yang berujung pada banyaknya kasus putus obat. Semakin banyaknya jumlah penderita TB resisten obat disebabkan oleh angka putus obat yang masih tinggi tersebut.

Vitamin D telah digunakan sejak zaman pre-antibiotik sebagai salah satu terapi untuk TB. Vitamin D dipercaya mampu mencegah ataupun membatasi infeksi TB melalui mekanisme pengikatan bentuk bioaktif dari vitamin $D$ yakni $(1,25$ dihidroksikalsiferol) dengan reseptor vitamin $D$ yang mampu meningkatkan ekspresi gen yang berperan dalam regulasi fungsi imun dan produksi sitokin. Reseptor vitamin $D$ banyak ditemukan pada sel-sel epitel bronkial dan pulmonal.

Dalam penelitiannya, Holick MF et al menemukan bahwa peningkatan risiko tuberculosis berkaitan dengan defisiensi vitamin D. Penemuan yang sama juga ditemukan dalam penelitian berbeda yang dilakukan oleh Wilkinson RJ et al, Selain itu, defisiensi vitamin $D$ ditemukan dapat meningkatkan risiko perkembangan TB latent menjadi TB aktif. Pemberian suplementasi vitamin D dapat meningkatkan aktivitas anti-mikrobial, mempercepat konversi sputum dan kultur, mengurangi inflamasi, meningkatkan clinical outcome, serta meningkatkan mediator untuk aktivitas anti-mikrobial.

Meskipun beberapa penelitian telah membuktikan manfaat suplementasi vitamin D pada tuberculosis, perlunya suplementasi vitamin D masih menjadi topik yang kontroversial. Hal ini dikarenakan beragamnya hasil penelitian mulai dari yang menyatakan adanya kebermanfaatan hingga yang tidak. Oleh karena situasi tersebut, penulis membuat tinjauan kasus berbasis bukti terutama terkait kebermanfaatan suplementasi vitamin D dalam meng-assist proses penyembuhan yang secara tidak langsung digambarkan dengan percepatan konversi sputum. Harapannya, dengan tinjauan ilmiah berbasis bukti ini, penulis dapat memberikan rekomendasi yang tepat terkait suplementasi vitamin D dapat diberikan kepada pasien di kemudian hari.

\section{Laporan Kasus}

Pasien laki-laki, 50 tahun, datang dengan keluhan sesak yang memberat sejak 1 minggu SMRS. Sesak dirasakan terus menerus dan memberat saat beraktivitas, membaik dengan istirahat. Pasien tidur dengan 2 bantal dan tidak mampu tidur terlentang tanpa bantal karena sesak. Nyeri dada dan bengkak kaki disangkal. Keluhan disertai dengan batuk sejak 10 hari SMRS. Batuk berdahak dengan bercak darah. Pasien memiliki riwayat penurunan berat badan tidak diukur. Nafsu makan pasien menurun. Pasien juga memiliki keluhan demam naik turun dan keringat malam.

Pada pemeriksaan fisik didapatkan takikardi 123x/menit, takipnea 28x/menit, fremitus paru kiri lebih lemah dari paru kanan, bunyi nafas vesikuler melemah pada paru kiri, ronki basah kasar pada paru kiri, serta nyeri tekan pada ICS 5 linea axillaris anterior sinistra. Pada pemeriksaan penunjang radiologi didapatkan kesan TB paru.

Pasien tuberculosis seringkali ditemukan dalam keadaan defisiensi vitamin D. Penelitian terdahulu menemukan bahwa suplementasi vitamin $D$ pada penderita tuberculosis memiliki berbagai manfaat seperti, mempercepat konversi sputum dan kultur, memiliki aktivitas antimikrobial, mengurangi inflamasi, serta meningkatkan clinical outcome, sehingga timbul pertanyaan. Apakah pemberian suplementasi vitamin $D$ mampu mempercepat waktu konversi sputum pada pasien tuberculosis?.

Rumusan pertanyaan dapat dilihat pada Tabel 1.

\section{METODE}

\section{Strategi pencarian}

Pencarian literatur dilakukan secara daring pada tanggal 24 Desember 2020 
menggunakan tiga databases terkemuka yakni PubMed, SCOPUS, dan Cochrane. Penelusuran dilakukan melalui kata kunci utama berupa "Tuberculosis", "Vitamin D", "Suplementation", dan "Sputum Conversion". Pencarian dilakukan juga menggunakan kata-kata sinonim dari kata kunci utama dengan operator Boolean. Adapun kombinasi kata kunci yang digunakan ditunjukkan oleh tabel 2.

\section{Seleksi artikel}

Seleksi artikel kemudian dilakukan setelah hasil penelusuran ditemukan. Proses seleksi dimulai dengan menyaring judul dan abstrak artikel yang memenuhi kriteria inklusi. Kriteria inklusi yang ditetapkan berupa: relevan dengan pertanyaan klinis, studi terapi (randomized controlled trial (RCT), meta-analisis dari RCT, serta systematic review dari RCT), dilakukan pada subjek manusia dewasa, serta berbahasa Inggris. Dari 28 artikel yang tersaring, 8 diantaranya memenuhi kriteria inklusi. Artikel yang memenuhi kriteria inklusi kemudian disaring kembali dengan melakukan eksklusi pada artikel yang sama. Terdapat 2 artikel yang lolos pada proses ini. Artikel yang lolos kemudian disaring berdasarkan kriteria eksklusi. Kriteria eksklusi yang ditetapkan berupa: naskah lengkap tidak tersedia serta menggunakan bahasa lain selain bahasa Inggris. Dari proses penyaringan tersebut, kedua artikel tersebut telah memenuhi baik kriteria inklusi maupun eksklusi. Proses lengkap seleksi artikel dapat dilihat pada Gambar 1. Kedua artikel terpilih terdiri atas 1 artikel meta analisis dan 1 artikel randomized controlled trial. Adapaun kedua artikel terpilih tersebut adalah:

1. Jollifee DA, Ganmaa D, Wejse C, Raqib R, Haq MA, Salahuddin N, et al. Adjunctive vitmin $\mathrm{D}$ in tuberculosis treatment: meta-analysis of individual participat data. Eur Respir J. 2019; in press

(https://doi.org/10.1183/13993003.020 03-2018)

2. Afzal A, Rathore R, Butt NF, Randhawa FA. Efficacy of vitamin D supplementation in achieving an early sputum conversion in smear positive pulmonary tuberculosis. Pak J Med Sci. 2018; 34(4): 849-854

\section{Telaah kritis literatur}

Setelah proses seleksi artikel dilakukan, didapatkan 2 artikel yang dapat dilanjutkan ke proses telaah kritis. Telaah kritis dilakukan untuk menilai validity, importance, dan applicability dari masingmasing artikel terpilih. Adapun proses telaah kritis dilakukan dengan menggunakan alat telaah kritis untuk studi terapi yang dikeluarkan oleh Centre for Evidence-Based Medicine (CEBM) University of Oxford, Inggris.

\section{HASIL \\ Metode Telaah Kritis}

Pada proses seleksi artikel, didapatkan dua artikel yakni satu artikel meta-analisis RCT oleh Jollifee DA et al, dan satu artikel RCT oleh Afzal $A$ et al. Kedua artikel ditelaah berdasarkan aspek validitas, kepentingan, dan kemamputerapan menggunakan kriteria terstandarisasi untuk studi meta-analisis dan terapi berdasarkan Centre of Evidence-Based Medicine, University of Oxford. Adapun resume dari masing-masing studi dijabarkan pada Tabel 3 dan Tabel 4.

\section{Aspek Validitas}

Dari aspek validitas, Jollifee DA et al, (2019) dan Afzal $A$ et al (2018) dapat dianggap valid berdasarkan tools appraisal mereka masing-masing. Adapun penjelasan aspek validitas untuk kedua studi tersebut dijabarkan pada Tabel 5.

\section{Aspek Kepentingan}

Meta-analisis Jollifee DA et al, (2019) melibatkan jumlah total 1.850 partisipan dari 8 studi individual. Hasil dari meta-analisis ini menunjukkan bahwa vitamin $D$ tidak memberikan pengaruh yang signifikan dalam percepatan waktu konversi kultur sputum pada populasi secara umum (aHR 1.06, 95\% Cl 0.91-1.23; $\mathrm{P}=0.44$; $\mathrm{P}$ for heterogeneity=0.84). Namun, berbeda dengan populasi pada umumnya, pada populasi dengan MDR-TB, vitamin D ditemukan mampu mempercepat waktu konversi kultur sputum secara signifikan (aHR 13.44, 95\% Cl 2.96-60.90). Efek serupa tidak ditemukan pada populasi yang masih sensitif dengan rifampicin dan/atau isoniazid (aHR 1.02, 95\% Cl 0.88-1.19; Pinteraction=0.02). Berbeda dengan konversi kultur sputum, pada konversi apusan sputum terdapat perubahan signifikan waktu konversi dengan pemberian suplementasi vitamin D (aHR $1.15,95 \% \mathrm{Cl}$ 1.01-1.31). Dari segi heterogenitas, 
didapatkan $\mathrm{I}^{2}$ sebesar $0.0 \%$. Nilai $\mathrm{I}^{2}<50$ menyatakan bahwa studi yang dipakai homogen. Pada RCT oleh Afzal A et al, (2018), digunakan sampel sebanyak 120 partisipan. Dari hasil penelitian ini, didapatkan bahwa pada minggu ke-12 follow up, didapatkan sebanyak $11.7 \%$ pasien pada kelompok intervensi mengalami konversi sputum sementara sebanyak $1.7 \%$ pada grup kontrol mengalami konversi sputum. Dari angka tersebut, didapatkan number-needed-totreat (NNT) sebesar 10, sehingga dibutuhkan 10 orang yang diberikan suplementasi untuk mendapatkan satu orang yang mendapat outcome berupa konversi sputum yang lebih cepat.

\section{PEMBAHASAN}

Berdasarkan hasil dari telaah kritis berdasarkan aspek validitas, kedua studi oleh Jollifee $D$ et al dan Afzal A et al secara umum telah memenuhi aspek validitas berdasarkan tools untuk penilaian validitas masing-masing, dimana artikel Jollifee $D$ et al menggunakan tools untuk systematic review sementara artikel Afzal $A$ et al menggunakan tools untuk randomized controlled trial. Meskipun demikian, terdapat beberapa kekurangan pada masing-masing artikel dalam memenuhi aspek validitasnya sehingga kedua artikel tersebut belum layak untuk dikatakan baik secara metodologi dan hasil yang didapatkan pada kedua studi belum sepenuhnya dapat dipertanggungjawabkan. Pada artikel Jollifee $D$ et al, terdapat kejanggalan pada penilaian homogenitas studi, dimana tidak terdapat pembahasan khusus untuk aspek heterogenitas. Selain itu, forest plot yang disertakan pada lampiran studi hanya menampilkan 4 dari 8 studi yang digunakan pada meta-analisis ini. Studi yang ditampilkan persebaran forest plot nya hanyalah studi oleh Martineau et al (2011), Daley et al (2015), Tukvadze et al (2015), serta Ganmaa et al (2017), sementara itu studi oleh Wejse et al (2009), Salahuddin et al (2013), Ralph et al (2013), serta Mily et al (2015) tidak diikutsertakan pada penilaian heterogenitas. Pada artikel Afzal $A$ et al, terdapat kekurangan pada poin homogenitas kelompok studi beserta blinding. Antara kelompok intervensi dan non-intervensi, karakter yang homogen hanyalah usia, BMI, serta kadar vitamin D pada awal permulaan studi.
Tidak terdapat tabel yang memuat penyetaraan/homogenitas pada aspek lain. Selain itu, parameter-parameter lab seperti kadar hemoglobin serum, kalsium darah, serta jumlah leukosit antara kedua kelompok pada permulaan studi terbukti tidak homogen dengan $p$-value $<0.001$. Studi ini juga tidak menyertakan keterangan mengenai ada tidaknya perlakuan blinding sehingga rentan akan bias.

Dari segi importance, kedua studi berhasil menunjukkan aspek kepentingan studinya masing- masing. Studi oleh Jollifee $D$ et al membuktikan bahwa vitamin $D$ tidak memberikan efek percepatan konversi kultur sputum pada populasi secara umumnya, namun mampu memberikan percepatan konversi kultur sputum pada kelompok MDR-TB. Selain itu, penelitian ini menemukan bahwa vitamin $D$ juga mampu mempercepat konversi apusan sputum pada populasi secara umum. Selaras dengan Jollifee $D$ et al, studi oleh Afzal $A$ et al juga menemukan bahwa pemberian suplementasi vitamin $D$ mampu mempercepat waktu konversi apusan sputum. Meskipun demikian, konversi apusan sputum memiliki validitas yang lebih rendah sebagai marker prognosis dalam melihat outcome tatalaksana TB. Dari segi applicability, kedua studi menunjukkan bahwa penggunaan suplementasi vitamin $\mathrm{D}$ akan mudah diaplikasikan di Indonesia. Vitamin D mudah didapatkan dengan harga yang bervariasi mulai dari yang terjangkau hingga yang mahal. Dari segi toksisitas/harm, tidak ditemukan adanya efek samping serius dari penggunaan vitamin D pada kedua studi. Tidak didapatkan kejadian batu ginjal pada kedua studi serta kejadian-kejadian diluar harapan tidak berbeda bermakna antara kelompok intervensi dengan non-intervensi.

Secara garis besar, studi yang dilakukan oleh Jollifee $D$ et al memiliki keunggulan baik secara metodologi maupun kekuatan bukti dibandingkan dengan artikel oleh Afzal $A$ et al. Dari penelitian Jollifee $D$ et al, dapat disimpulkan bahwa vitamin $D$ tidak memberikan efek percepatan pada konversi kultur sputum pada populasi secara umum meskipun mampu mempercepat konversi apusan sputum dan memiliki efek immunomodulator. Padahal, konversi kultur sputum merupakan parameter yang penting karena dapat 
digunakan sebagai acuan untuk memprediksi kemungkinan kegagalan pengobatan, kekambuhan, serta profil kultur secara longitudinal di kemudian hari. Pada penelitian ini didapatkan median konversi kultur sputum pada kelompok vitamin $D$ adalah 21 hari dan pada kelompok kontrol 26 hari. Penemuan ini selaras dengan penelitian oleh Ganmaa et al yang menyatakan tidak adanya perbedaan bermakna secara statistik pada waktu konversi kultur sputum antara kelompok vitamin $\mathrm{D}$ dan kontrol (aHR 1.09, $96 \% \mathrm{Cl}$ 0.86-1.36, $\mathrm{p}=0.48$ ). Kesimpulan yang sama juga diperoleh pada penelitian yang dilakukan oleh Daley et al, Martineau et al (aHR 1.39, 95\% Cl, 0.90-2.16; $\mathrm{p}=0.14)$, dan Tukvadze et al.

Meskipun demikian, vitamin D ditemukan memiliki peranan dalam mempercepat konversi kultur sputum pada populasi tertentu, seperti pada populasi MDR-TB serta kelompok polimorfisme gen reseptor vitamin $\mathrm{D} t t$ dan Taql. Peningkatan waktu konversi sputum pada populasi MDR-TB diduga terjadi sebagai akibat ketidak efektifan penggunaan OAT pada populasi kelompok MDR-TB sehingga efek terapi yang bersifat host-directed seperti suplementasi vitamin $D$ akan mampu memberikan manfaat yang lebih besar dalam membuat implikasi klinis. Adapun efek polimorfisme dari gen reseptor vitamin $\mathrm{D} t t$ dan Taql diduga akibat pengaruh pada gen ini terhadap stabilitas mRNA. Namun, telah muncul studi lain yang membantah hubungan tersebut sehingga mekanisme percepataan konversi sputum pada kelompok populasi dengan polimorfisme gen tersebut belum sepenuhnya dipahami.

Pada penelitian yang dilakukan Ganmaa et al, vitamin D terbukti memiliki efek anti-inflamasi yang secara langsung digambarkan dengan percepatan resolusi neutrofilia dan perbaikan rasio limfosit:monosit yang merupakan marker inflamasi pulmoner pada hewan percobaan. Meskipun memiliki manfaat, efek dari vitamin $D$ dipercaya tertutupi oleh efek dari OAT yang bekerja pada fase intensif. Oleh karena itu, kinerja vitamin D dipercaya akan tampak pada setting dimana OAT tidak efektif bekerja atau pada setting pencegahan TB. Dari segi keamanan, semua studi menunjukkan bahwa penggunaan vitamin $D$ aman digunakan dan tidak menimbulkan efek samping yang berbeda bermakna pada kelompok kontrol. Harganya juga murah dan mudah didapatkan pada berbagai apotik atau marketplace online di Indonesia. Meskipun demikian, sebagaimana yang telah dijelaskan sebelumnya, ketidakefektifan vitamin D dalam mempercepat waktu konversi kultur sputum terutama pada kelompok dengan pengobatan intensif OAT membuat tidak perlunya justifikasi pemakaian vitamin D untuk saat ini pada kelompok tersebut. Suplementasi vitamin D dapat dipertimbangkan setelah dilakukan penelitian lebih lanjut mengenai kebermanfaatan vitamin $\mathrm{D}$ pada populasi khusus yang dinilai akan mendapat manfaat lebih, seperti pada populasi MDRTB dan populasi yang ingin melakukan pencegahan terhadap TB.

Kelebihan dari Jollifee $D$ et al dibandingkan dengan studi meta-analisis bertema serupa sebelumnya yakni, menggunakan data mentah individual dari masing-masing artikel yang digunakannya, bias minimal, sampel yang bervariasi, serta hanya menganalisis subjek penelitian yang terkonfirmasi memiliki TB pada awal studi. Pengunaan data mentah individual dari masing-masing studi memungkinkan Jollifee $D$ et al untuk dapat melakukan analisis sub- grup. Penggunaan sampel yang bervariasi mendukung kemampuan artikel ini untuk dapat digeneralisasi di populasi umum. Adapun kelemahan dari artikel ini adalah, tidak tersedianya data end-of treatment outcome serta tidak diikutsertakannya keseluruhan studi pada penilaian heterogenitas.

Kelebihan dari Afzal $A$ et al adalah dapat membuktikan secara signifikan percepatan waktu konversi apusan sputum, sementara kelemahanya adalah bukan merupakan trial multicenter, tidak terdapat blinding serta homogenisasi kelompok pada awal studi kurang adekuat

\section{KESIMPULAN}

Pemberian suplementasi vitamin $D$ tidak mempercepat konversi kultur sputum pada populasi secara umumnya. Pemberian suplementasi vitamin D mempercepat konversi sputum hanya pada populasi khusus seperti MDR-TB, serta individu dengan polimorfisme gen reseptor vitamin $\mathrm{D} t t$ dan Taql. Pemberian suplementasi vitamin D, walaupun tidak dapat mempercepat waktu konversi kultur sputum, terbukti dapat mempercepat waktu 
konversi apusan sputum.

\section{SARAN}

Diperlukan penelitian lebih lanjut dengan jumlah sampel yang lebih besar untuk meneliti efek suplementasi vitamin D pada percepatan waktu konversi kultur sputum pada populasi tertentu, khususnya MDR-TB.

Diperlukan meta-analisis lanjutan, yang selain mengikutsertakan studi terbaru, juga memperbaiki kekurangan pada meta-analisis yang tersedia sampai saat ini, khususnya kekurangan terkait penilaian heterogenitas.

\section{UCAPAN TERIMA KASIH}

Terima kasih pada Fakultas Kedokteran Universitas Indonesia dalam akses jurnal yang prabayar.

\section{DAFTAR PUSTAKA}

Afzal A, R. R. B. N. R. F., 2018. Efficacy of Vitamin $D$ supplementation in achieving an early sputum conversion in smear positive pulmonary tuberculosis. Pak $\mathrm{J}$ Med Sci, 34(4), pp. 849-854.

Daley P, J. V. J. K. S. J. L. A. V. R., 2015. Adjunctive vitamin $D$ for treatment of active tuberculosis in India: a randomized, double-blind, placebocontrolled trial. Lancet Infect Dis, 15(5), pp. 528-534.

Dhuria M, S. N. I. G., 2008 Jan. Impact of tuberculosis in the quality of life. Indian J Community Med, 33(1), pp. 58-59.

DK, M., 2014. The role of vitamin D in tuberculosis. J Clin Trans Endocrinol, 1(4), pp. 167-169.

Ganmaa D, M. B. F. W. S. D. W. W. B. P., 2017. High- dose vitamin D3 during tuberculosis treatment in Mongolia: a randomized controlled trial. $\mathrm{Am} \mathrm{J}$ Respir Crit Care Med, 195(5), pp. 628-637.

Jollifee DA, G. D. W. C. R. R. H. A. S. N., 2019. Adjunctive vitamin $D$ in tuberculosis treatment: metaanalysis of individual participant data. Eur Respir J, 53(3), p. 1802003.

Martineau AR, T. P. B. G. H. Y. I. K. C. A., 2011. High dose vitamin D3 during intensive-phase treatment of tuberculosis: a antimicrobial pulmonary double-blind randomized controlled trial. Lancet, 377 (9761), pp. 242- 250.

MF, H., 2006. High prevalence of vitamin D inadequacy and implications for health. Mayo Clin Proc, 81(3), p. 353-373.

Mily A, R. R. K. S. A. A. R. Z. L., 2015. Significant ffects of oral phenylbutyrate and vitamin D3 adjunctive therapy in pulmonary tuberculosis: a randomized controlled trial. PLOS ONE, 10(9), p. e0138340.

Organization, W. H., 2019. Global tuberculosis report 2019 factsheet. [Online]

Available at:

https://www.who.int/tb/publications/f actsheet global.pdf?ua $=1$

[Diakses 24 Desember 2020].

Organization, W. H., 2019. Global tuberculosis report country profiles. [Online]

Available at:

https://www.who.int/tb/data/GTBrep ortCountryProfiles.pdf?ua $=1$ [Diakses 24 Desember 2020].

Ralph AP, W. G. P. G. K. E. W. A. T. E., 2013. L- arginine and vitamin D adjunctive therapies in pulmonary tuberculosis: a randomized, double blind, placebo-controlled trial. PLoS ONE, 8(8), p. e70032.

Salahuddin N, A. F. H. Z. R. N. A. M. M. F., 2013. Vitamin D accelerates clinical recovery from tuberculosis: results of the SUCCINCT study [supplementary cholecalciferol in recovery from tuberculosis]: a randomized, placebo-controlled, clinical trial of vitamin $D$ Supplementation in patients. BMC Infectious Disease, 13(22).

Tukvadze N, S. E. K. M. H. G. E. K. S. N., 2015. High-dose vitamin D3 in adults with pulmonary: tuberculosis: a doubke-blind randomized controlled trial. Am J Clin Nutr, 102(5), pp. 1059-1069.

Wang J, F. M. Y. S. Z. J. L. X., 2018. Efficacy and safety of vitamin D supplementation for pulmonary tuberculosis: a systematic review and meta-analysis. Iran J Public Health, 47(4), p. 466-472.

Wejse C, G. V. R. P. G. P. A. P. L. I., 2009. Vitamin $D$ as supplementary treatment for tuberculosis: a double- 
blind, randomized, placebocontrolled trial. Am J Respir Crit Care Med, 179(9), pp. 843-850.

Wilkinson RJ, L. M. T. Z. P. P. P. G. L. A. 2000. Influence of vitamin D deficiency and vitamin $\mathrm{D}$ receptor polymorphisms on tuberculosis among Gujarati Asians in west London: a case-control study.
Lancet, 355(9204), p. 618-621. 
Tabel 1.

Rumusan pertanyaan klinis berdasar Masalah

\begin{tabular}{ll}
\hline P & Pasien Tuberkulosis \\
I & Suplementasi Vitamin D \\
C & Tanpa Suplementasi \\
O & Waktu konversi sputum \\
Jenis Pertanyaan & Terapi \\
Jenis Studi & $\begin{array}{l}\text { Randomized Controlled Trial (RCT), meta analisis RCT, Systematic } \\
\text { review }\end{array}$ \\
\hline
\end{tabular}

Tabel 2.

Strategi Pencarian Literatur

\begin{tabular}{|c|c|c|}
\hline Database & Kata Kunci Pencarian & Jumlah Artikel \\
\hline \multirow[t]{13}{*}{ Pubmed } & ((((((((("Tuberculosis"[Mesh]) & 7 \\
\hline & tuberculosis[Title/Abstract]) OR TB[Title/Abstract]) & \\
\hline & TBC $[$ Title/Abstract])) OR $\quad$ t.b.[Title/Abstract])) AND & \\
\hline & (((("Vitamin D"[Mesh]) OR Vitamin D[Title/Abstract]) OR vit & \\
\hline & $\mathrm{D}[$ Title/Abstract]) OR vit- $\quad \mathrm{D}[$ Title/Abstract] $)) \quad$ AND & \\
\hline & $((()((("$ "Dietary $\quad$ Supplements"[Mesh]) OR Dietary & \\
\hline & Supplements[Title/Abstract]) OR & \\
\hline & supplement[Title/Abstract]) & \\
\hline & Supplementation[Title/Abstract]) & \\
\hline & Supplementations[Title/Abstract]) & \\
\hline & supplement[Title/Abstract]) & \\
\hline & supplements[Title/Abstract])) & \\
\hline & Conversion[Title/Abstract] & \\
\hline Scopus & $\begin{array}{l}\text { ( TITLE-ABS- KEY ( ( ( ( tuberculosis OR tb ) OR tbc }) \\
\text { OR t.b. ) }) \text { AND TITLE -ABS-KEY ( ( ( vitamin AND } \\
\text { d OR vit AND d ) OR vit- } d)) \text { AND TITLE-ABS- } \\
\text { KEY ( ( ( ( ( (dietary AND supplements OR dietary AND } \\
\text { supplem ent ) OR supplementations ) OR } \\
\text { supplementation ) OR supplemen } t) \text { OR supplements }) \\
\text { ) AND TITLE-ABS- KEY ( sputum AND conversion )) }\end{array}$ & 20 \\
\hline Cochrane & $\begin{array}{l}\text { ( ( ( tuberculosis OR tb ) OR tbc ) OR t.b. ) in Title } \\
\text { Abstract Keyword AND ( ( vitamin D OR vit D ) OR vit-d ) } \\
\text { in Title Abstract Keyword AND ( ( ( ( ( ( dietary } \\
\text { supplements OR dietary supplement ) OR } \\
\text { supplementations ) OR supplementation ) OR } \\
\text { supplement ) OR supplements ) in Title Abstract Keyword } \\
\text { AND Sputum Conversion in Title Abstract Keyword }\end{array}$ & 1 \\
\hline
\end{tabular}


Tabel 3.

Resume meta analisis Jolifee DA et al

\begin{tabular}{|c|c|c|c|c|c|c|}
\hline Author & $\begin{array}{l}\text { Jenis } \\
\text { Studi }\end{array}$ & Populasi & Intervensi & $\begin{array}{l}\text { Primary } \\
\text { Outcome }\end{array}$ & $\begin{array}{c}\text { Durasi } \\
\text { follow-up }\end{array}$ & Hasil \\
\hline $\begin{array}{c}\text { Jolifee DA } \\
\text { et al } \\
(2018)^{8}\end{array}$ & $\begin{array}{c}\text { Meta- } \\
\text { analisis } \\
\text { RCT }\end{array}$ & $\begin{array}{l}\text { Besar sampel: } \\
1850 \\
\text { Range usia: } 15-86 \\
\text { tahun } \\
\text { Sampel yang } \\
\text { digunakan untuk } \\
\text { analisis konversi } \\
\text { kultur sputum: } \\
1163 \\
\text { Sampel yang } \\
\text { digunakan untuk } \\
\text { analisis konversi } \\
\text { apusan sputum: } \\
1611 \\
\text { Lokasi: Lahore, } \\
\text { Pakistan }\end{array}$ & $\begin{array}{l}\text { Bervariasi } \\
\text { (dapat } \\
\text { dilihat pada } \\
\text { ringkasan } \\
\text { per studi di } \\
\text { Tabel 4) }\end{array}$ & $\begin{array}{l}\text { Waktu } \\
\text { konversi } \\
\text { kultur } \\
\text { sputum } \\
\text { Secondary } \\
\text { outcome: } \\
\text { waktu } \\
\text { konversi } \\
\text { apusan } \\
\text { sputum, } \\
\text { berat } \\
\text { badan pada } \\
\text { minggu ke- } \\
8 \text {, } \\
\text { terjadinya } \\
\text { adverse } \\
\text { event }\end{array}$ & $\begin{array}{l}8 \text { minggu } \\
-8 \text { bulan }\end{array}$ & $\begin{array}{l}\text { Pemberian Vit D } \\
\text { tidak mempercepat } \\
\text { waktu konversi kultur } \\
\text { sputum pada } \\
\text { penderita TB secara } \\
\text { keseluruhan (aHR } \\
1.06,95 \% \mathrm{CI} 0.91 \text { - } \\
1.23 \text { ). Namun } \\
\text { mempercepat waktu } \\
\text { konversi kultur } \\
\text { sputum pada } \\
\text { penderita MDR PTB } \\
\text { (aHR } 13.44,95 \% \mathrm{CI} \\
2.96-60.90) \text {. Vitamin } \\
\text { D mempercepat } \\
\text { waktu konversi } \\
\text { apusan sputum (aHR } \\
1.15,95 \% \mathrm{Cl} 1.01 \text { - } \\
1.31 \text { ) }\end{array}$ \\
\hline
\end{tabular}

Tabel 4.

Tabel resume Afzal A et al

\begin{tabular}{|c|c|c|c|c|c|c|}
\hline Author & $\begin{array}{l}\text { Jenis } \\
\text { Studi }\end{array}$ & Populasi & Intervensi & $\begin{array}{l}\text { Primary } \\
\text { Outcome }\end{array}$ & $\begin{array}{l}\text { Durasi } \\
\text { follow- } \\
\text { up }\end{array}$ & Hasil \\
\hline $\begin{array}{l}\text { Afzal A et } \\
\text { al }(2018)^{17}\end{array}$ & $\mathrm{RCT}$ & $\begin{array}{l}\text { Sampel awal: } 120 \\
\text { Sampel akhir: } 120 \\
\text { Rerata usia } \\
\text { intervensi: } 37.18 \\
\text { Rerata usia non } \\
\text { intervensi: } 39.02 \\
\text { Lokasi: Lahore. } \\
\text { Pakistan }\end{array}$ & $\begin{array}{l}2.5 \mathrm{mg} \text { Vit D } \\
\text { diberikan } \\
\text { secara IM } \\
\text { setiap } 2 \\
\text { minggu } \\
\text { sekali } \\
\text { selama } 3 \\
\text { bulan }\end{array}$ & $\begin{array}{l}\text { Waktu } \\
\text { konversi } \\
\text { sputum }\end{array}$ & $\begin{array}{l}12 \\
\text { minggu }\end{array}$ & $\begin{array}{l}\text { Pemberian } \\
\text { suplementasi Vit D } \\
\text { mampu mengkoreksi } \\
\text { defisiensi vit D beserta } \\
\text { mempercepat konversi } \\
\text { sputum (p value = } \\
0.028 \text { ) }\end{array}$ \\
\hline
\end{tabular}


Tabel 5.

Telaah kritis aspek validitas

\begin{tabular}{|c|c|c|}
\hline Parameter & Ket & Afzal A et all, (2018) ${ }^{8}$ \\
\hline Randomisasi & + & $\begin{array}{l}\text { Kelompok intervensi dan kontrol di randomisasi dengan } \\
\text { menggunakan metode lotere }\end{array}$ \\
\hline $\begin{array}{l}\text { Homogenitas } \\
\text { kelompok studi } \\
\text { saat permulaan } \\
\text { penelitian }\end{array}$ & - & $\begin{array}{l}\text { Penulis tidak menjabarkan secara detail mengenai karakteristik } \\
\text { basal yang disetarakan selain usia, BMI, dan kadar vitamin D. } \\
\text { Padahal, terdapat berbagai faktor risiko lain yang dapat } \\
\text { disetarakan. Selain itu, terdapat heterogenitas pada hasil lab } \\
\text { kedua studi dengan parameter berupa kadar hemoglobin serum, } \\
\text { leukosit, dan kalsium darah (p-value }<0.001 \text { ) }\end{array}$ \\
\hline $\begin{array}{l}\text { Perlakuan yang } \\
\text { sama }\end{array}$ & + & $\begin{array}{l}\text { Kedua kelompok diperlakukan secara sama diluar pemberian } \\
\text { vitamin D }\end{array}$ \\
\hline $\begin{array}{l}\text { Loss to follow-up } \\
<20 \%\end{array}$ & + & Pada penelitian ini tidak terdapat loss to follow-up \\
\hline Blinding & - & $\begin{array}{l}\text { Tidak terdapat keterangan mengenai blinding sehingga } \\
\text { disimpulkan pada penelitian ini tidak dilakukan blinding. }\end{array}$ \\
\hline Level of evidence & & III \\
\hline
\end{tabular}

Tabel 6.

Telaah kritis aspek aplikabilitas pada kedua studi

\begin{tabular}{|c|c|c|}
\hline Parameter & Jollifee DA et al, (2019) ${ }^{8}$ & Afzal A et all, $(2018)^{17}$ \\
\hline $\begin{array}{l}\text { Kemiripan subjek } \\
\text { penelitian dengan } \\
\text { pasien }\end{array}$ & $\begin{array}{l}\text { - Range usia yang digunakan } \\
\text { sesuai dengan pasien, yakni } \\
15-86 \text { tahun } \\
\text { - Populasi yang digunakan } \\
\text { sangat beragam karena } \\
\text { sampel berasal dari } 8 \text { negara } \\
\text { yang tercakup dalam } 3 \\
\text { komponen. Salah satu studi } \\
\text { melakukan pengambilan } \\
\text { sampel di Indonesia, namun } \\
\text { sampel yang diambil hanya } \\
\text { dari Timika, Papua } \\
\text { - Pasien yang diambil } \\
\text { merupakan pasien yang baru } \\
\text { didiagnosis dengan } \\
\text { tuberculosis }\end{array}$ & $\begin{array}{l}\text { - Rerata usia yang digunakan di } \\
\text { penelitian ini adalah } 37.18 \text { untuk } \\
\text { kelompok intervensi dan } 39.02 \\
\text { untuk kelompok non-intervensi. } \\
\text { Sulit menilai kesesuaian dengan } \\
\text { populasi karena data range usia } \\
\text { tidak disediakan } \\
\text { - Populasi yang digunakan } \\
\text { hanyalah populasi Timur Tengah } \\
\text { dari Lahore, Pakistan sehingga } \\
\text { tidak sesuai dengan pasien } \\
\text { - Pasien yang diambil merupakan } \\
\text { pasien yang baru didiagnosis } \\
\text { dengan tuberkulosis }\end{array}$ \\
\hline $\begin{array}{l}\text { Feasibilitas terapi } \\
\text { di praktik klinis }\end{array}$ & $\begin{array}{l}\text { - Suplementasi vitamin D dapat d } \\
\text { Suplementasi vitamin D banyak } \\
\text { dan tersedia online. Harganya b } \\
\text { hingga yang lebih mahal } \\
\text { - Pemberian suplementasi melalui } \\
\text { suplementasi akan mudah untuk }\end{array}$ & $\begin{array}{l}\text { dijumpai dengan mudah di Indonesia. } \\
\text { k tersedia pada toko-toko obat besar } \\
\text { bervariasi mulai dari yang terjangkau } \\
\text { ui jalur peroral sehingga administrasi } \\
\text { k dilakukan pasien secara mandiri }\end{array}$ \\
\hline $\begin{array}{l}\text { Benefit melebihi } \\
\text { harm }\end{array}$ & $\begin{array}{l}\text { - Suplementasi vitamin D tidak } \\
\text { menimbulkan efek samping } \\
\text { yang mengkhawatirkan selama } \\
\text { dikonsumsi dalam batas dosis } \\
\text { aman } \\
\text { - Suplementasi vitamin D tidak } \\
\text { menimbulkan benefit untuk } \\
\text { populasi pasien tuberculosis } \\
\text { secara umum, namun diduga } \\
\text { memiliki manfaat untuk } \\
\text { populasi pasien MDR-TB } \\
\text { dalam hal konversi sputum }\end{array}$ & $\begin{array}{l}\text { - Suplementasi vitamin D tidak } \\
\text { menimbulkan efek samping } \\
\text { yang mengkhawatirkan selama } \\
\text { dikonsumsi dalam batas dosis } \\
\text { aman } \\
\text { - Suplementasi vitamin D } \\
\text { memiliki benefit yang melebihi } \\
\text { harm karena mampu } \\
\text { mempercepat waktu konversi } \\
\text { sputum secara signifikan }\end{array}$ \\
\hline
\end{tabular}




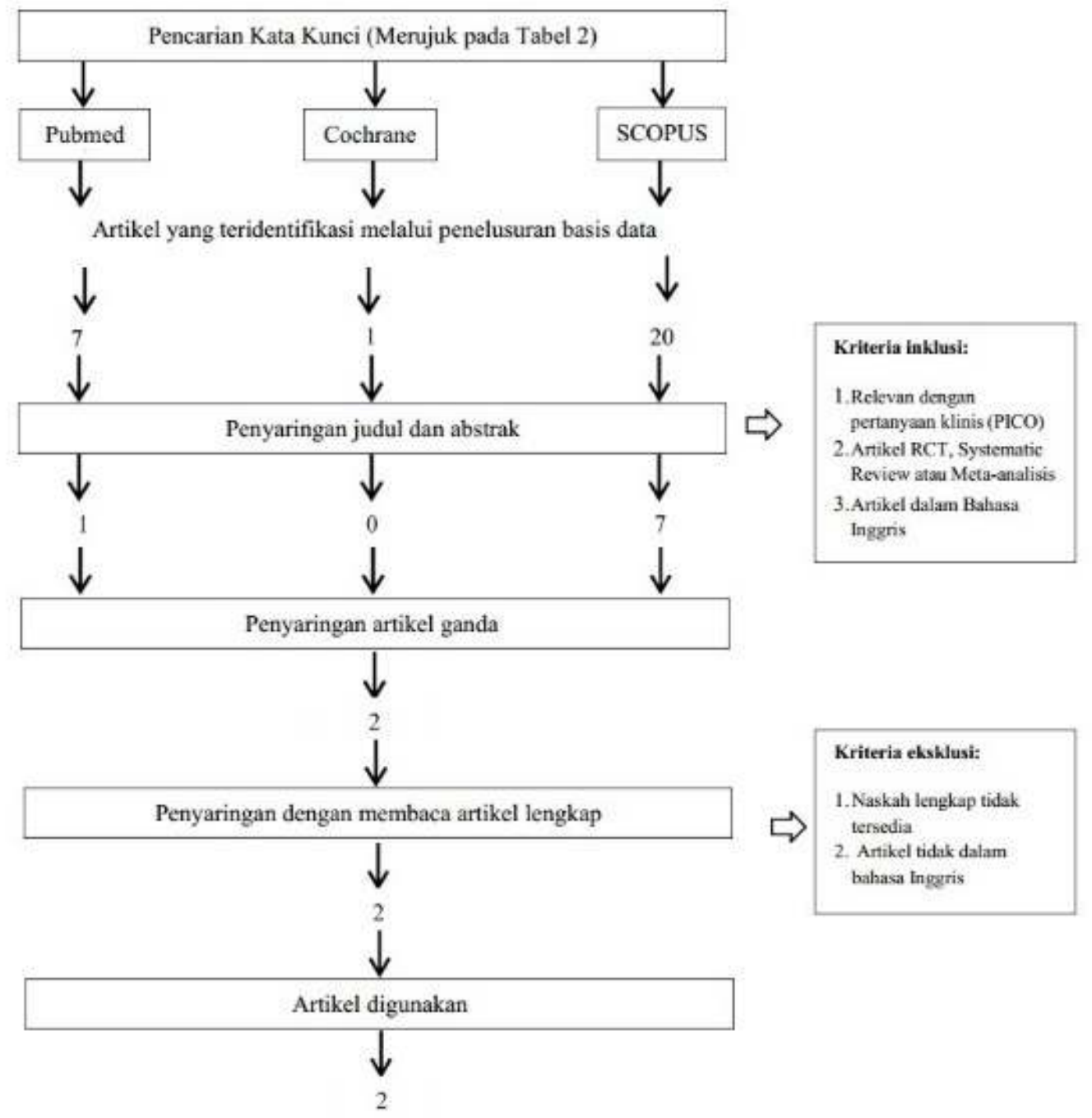

Gambar 1.

Diagram Alur Penelusuran Literatur dan Seleksi Artikel. 